\title{
De índio a guarda nacional: cidadania e direitos indígenas no Império (Vila de Itaguaí, 1822-1836)
}

Vânia Maria Losada Moreira

Depois de outorgada a Constituição de 1824, os índios da vila de Itaguaí foram considerados cidadãos pelo novo regime e, mais tarde, alistados como praças em duas armas da Guarda Nacional. Por razões estranhas à lei, contudo, ao serem classificados como cidadãos e guardas nacionais foram privados de possuírem legalmente as terras que ocupavam de forma legítima. $\mathrm{O}$ objetivo deste artigo é problematizar este episódio, ocorrido logo após a Independência, especialmente a correlação entre etnicidade, cidadania e territorialidade.

No atual estágio de desenvolvimentos das pesquisas sobre os índios durante o regime imperial é prematuro tentar definir o que aconteceu com os índios de Itaguaí como "típico" ou "atípico", pois ainda não existe um acúmulo de conhecimento sobre a situação dos índios depois da Independência. Trata-se, contudo, de um caso bastante significativo. De um lado, porque temos testemunhos históricos sobre eles durante o período pós-independência, o que nem sempre acontece em relação a outros grupos ou comunidades. De outro, porque, neste episódio, pode-se verificar o surgimento e a utilização de um argumento que, embora não tivesse amparo na legislação, acabou criando raízes profundas no imaginário, nos costumes e no sistema político nacional: o argumento de que ou se é "índio", ou se é "cidadão brasileiro", e só aos "índios" estavam garantidos os direitos legais sobre as terras que ocupavam.

$\mathrm{O}$ artigo está dividido em duas partes. ${ }^{1} \mathrm{Na}$ primeira, faço uma reflexão sobre o debate indigenista no período pós-independência, enfocando principalmente a contribuição de José Bonifácio de Andrada e Silva, dos constituintes de 1823 e da Constituição de 1824 para a definição dos direitos e deveres dos índios no Império do Brasil. $\mathrm{Na}$ segunda, analiso o caso dos índios da vila de Itaguaí, que não tiveram seu patrimônio territorial regularizado por serem classificados como guardas nacionais.

\section{Da Constituinte à Constituição: o novo pacto político e os índios}

No contexto da emancipação política, as ideias de José Bonifácio de Andrada e Silva sobre a "civilização" dos índios "bravos" são um marco incontornável, quando o assunto é a construção do indigenismo propriamente nacional. Sua posição na estrutura política do período, ocupando espaços no Estado, no Parlamento e na imprensa, ${ }^{2}$ e a abrangência de seus argumentos fizeram dele uma referência na questão indígena. A influência de Bonifácio está presente, por exemplo, no "Regulamento para a civilização dos índios botocudos nas margens do rio Doce", de 28 de janeiro de 1824, um dos primeiros documentos sobre os índios produzidos no Primeiro Reinado. O regulamento foi assinado por João Severino Maciel da Costa, que substituiu Bonifácio à frente da Secretaria de Estado dos Negócios do Império, e direcionava-se à província do Espírito Santo, tendo como objetivo precípuo aldear e civilizar os índios Botocudos que, desde 1808, sofriam os rigores da guerra ofensiva decretada por D. João VI. ${ }^{3}$

Mas a influência de José Bonifácio no campo do indigenismo nacional não resulta tanto da aceitação ou da execução com sucesso de seus ideais. Afinal, suas proposições não foram incorporadas à Constituição outorgada em 1824 e, até a promulgação do "Regulamento das missões de catequese e civilização dos índios", em 1845, durante o Segundo Reinado, foram poucas as ações institucionais sistemáticas que buscaram pôr em prática pelo menos algumas de suas sugestôes para ressocializar os índios egressos dos sertôes. Apesar disso, foi à sombra dos "Apontamentos para a civilização dos índios bravos do Império do Brasil” " que se desenvolveu a política e o debate indigenista no Império e mesmo na Repú- 
blica, pois a proposta de Bonifácio era não apenas mais apropriada ao discurso oficial de um Estado que se dizia e queria-se "civilizado", mas também a que mais bem equacionava a transição do indigenismo colonial para o propriamente nacional, aparentemente não propondo rupturas significativas.

Bonifácio apresentou suas ideias sobre a civilização dos índios "bravos" primeiro às Cortes de Lisboa, em 1821. Nessa ocasião, também Francisco Muniz Tavares, de Pernambuco; Domingos Borges de Barros, da Bahia; e José Caetano Ribeiro da Cunha e Francisco Ricardo Zane, do Pará, levaram às Cortes Gerais de Lisboa projetos sobre os índios. ${ }^{5}$ Consumada a Independência, ele reapresentou a proposta com algumas modificações, em 1823, à Assembleia Constituinte do Império, recebendo parecer favorável, que foi aprovado em 18 de junho do mesmo ano. Além disso, ficou decidido que o texto seria publicado para "discussão na Assembleia e para a instrução da Nação". ${ }^{6} \mathrm{O}$ documento "Apontamentos para a civilização dos índios bravos do Império do Brasil” é, resumidamente, um programa de assimilação e ressocialização da população indígena "brava” por meio de métodos "brandos", que deve ser lido e interpretado de acordo com as preocupaçôes de Bonifácio naquele momento de estruturação do Brasil como uma Monarquia constitucional e independente de Portugal. Trata-se, além disso, de um documento bem-circunstanciado, dividido em duas partes principais.

Na primeira parte, Bonifácio demonstra bom conhecimento sobre a legislação colonial relativa aos índios, bem como sobre os óbices sociais, políticos e históricos que impediram ou frustraram a plena consecução dos ideais assimilacionistas que animavam as ordens legais. Também apresenta domínio sobre os processos efetivamente implantados pela Coroa para a "civilização" da população autóctone, comentando a diversidade de povos e culturas encontrados pelos portugueses no momento inicial da conquista; as guerras e os acordos; a experiência missionária colonial; e o Diretório pombalino. A primeira parte dos "Apontamentos" configura-se, portanto, como uma sólida memória sobre a civilização dos índios, a partir da qual o autor legitima sua posição no interior do debate indigenista e, mais ainda, assenta os argumentos básicos de seu próprio ponto de vista sobre a questão.

Dessa parte inicial, três pontos merecem ser destacados, pois constituem a espinha dorsal de seu projeto civilizacional. Em primeiro lugar, a convicção de que os índios estavam no "estado selvático". Mais ainda, nessa condição "primitiva", os homens eram dotados do "lume natural da razão" e capazes, por isso mesmo, de civilizar-se. Bonifácio acreditava, portanto, na perfectibilidade do indígena. Em segundo, a necessidade de criação de novos aldeamentos ou de reativação de antigos, onde os índios retirados dos sertôes e das florestas pudessem ser reunidos, fixados, controlados e ressocializados ("civilizados"). Em terceiro, o entendimento que a melhor forma de civilizar os indígenas era por meio do método "brando", que incluía um leque bastante variado de ações, como a educação, o trabalho, a agricultura, o comércio, o convívio com os brancos, os casamentos mistos, dentre outros.

Versado nas ideias iluministas, Bonifácio resumia sua profunda convicção na perfectibilidade humana com a seguinte afirmação: "o homem primitivo nem é bom, nem é mal naturalmente, é um mero autômato, cujas molas podem ser postas em ação pelo exemplo, educação e benefícios". ${ }^{9}$ Seu apreço pela educação como meio civilizacional fez dele um franco admirador da ação jesuítica entre os índios. Segundo sua opinião, o Império deveria imitar e aperfeiçoar os métodos da Companhia de Jesus, expurgando a "teocracia" e incentivando o intercâmbio econômico e matrimonial entre índios e não índios, especialmente com brancos e mulatos. Coerente com tais ideias, não poupou de críticas severas os "métodos violentos" de civilização - e, indiretamente, a guerra ofensiva (guerra justa) decretada pelo príncipe regente D. João, em 1808, contra os Botocudos -, pois "foi ignorância crassa, para não dizer brutalidade, querer domesticar e civilizar índios à força das armas, e com soldados e oficiais pela maior parte sem juízo, prudência e moralidade". ${ }^{10}$

$\mathrm{Na}$ segunda parte dos "Apontamentos", José Bonifácio expôs, por meio de 44 itens, os principais "meios" que a "razão" e a "experiência" ensinavam para melhor alcançar a civilização dos indígenas. ${ }^{11}$ No topo de suas considerações, ele expôs, em primeiríssimo lugar, a "Justiça, não esbulhando mais os índios, pela força, das terras que ainda lhes restam, e de que são legítimos senhores”. ${ }^{12}$ Seguem-se a essa 
orientação muitas outras versando sobre o comércio; os matrimônios; a formação e a administração de aldeias; as "bandeiras" para buscar índios "bravos" e povoar novas ou antigas aldeias; os missionários; a educação; os mercados e as feiras; a vacinação e a prevenção de doenças; os tipos de trabalhos mais adequados aos índios em razão de sua índole e seu estado civilizatório; os vencimentos e os contratos de trabalho; e as formas de garantir que os direitos indígenas fossem observados. No $20^{\circ}$ item, por exemplo, pode-se ler a seguinte orientação de Bonifácio: "Nas grandes aldeias centrais, além do ensino de ler, escrever e contar, e catecismo, se levantarão escolas práticas de artes e ofícios...". ${ }^{13}$

São muitas as sugestôes apresentadas por Bonifácio na segunda parte do documento, e, embora não haja a intenção, neste artigo, de avaliar todos os aspectos de seu projeto, é importante fazer algumas considerações de caráter geral. A primeira observação é que, apesar da simpatia de Bonifácio pelos índios, ele era um homem do seu tempo e construiu um ponto de vista bastante etnocêntrico sobre eles. Para Bonifácio, a população indígena era, na melhor das hipóteses, uma espécie de página em branco, sem cultura, Estado, religião e vida social realmente apreciável, que poderia ser facilmente moldada segundo o padrão cultural e comportamental europeu. Os índios também eram, para ele, "inconstantes", "preguiçosos" e "traiçoeiros". ${ }^{14}$ A segunda observação diz respeito à sua predileção pelo método "brando" de civilização dos índios, que, é preciso frisar, não supunha a ausência do uso da força. Sua proposta previa a redução dos índios "bravos" ao modo de vida sedentário dos aldeamentos. Isso significava, na prática, um intenso processo de transformação na vida tradicional das populações indígenas, como o trabalho na lavoura, o trabalho para o Estado, a catequese, a participação nas redes de comércio e a aprendizagem de ofícios e das primeiras letras. Assim, no $10^{\circ}$ item, adverte Bonifácio:

Para que estes missionários [dos aldeamentos] sejam respeitados pelos índios, e possam coibir prontamente os tumultos e desordens que estes fizerem depois de aldeados, estabelecer-se-ão nas distâncias necessárias e adequadas pequenos presídios militares, cujos comandantes obrarão de acordo com os mesmos missionários, e lhes darão todo favor e auxílio requerido. ${ }^{15}$

A última observação refere-se à posição do indigenismo de Bonifácio ante a herança colonial. A ideia de reunir e segregar os índios em um só local (as aldeias), para tornar mais efetiva sua catequização e civilização, foi testada primeiramente por Manuel da Nóbrega e Anchieta, em São Vicente, em substituição à pregação missionária itinerante. A partir de 1556, a reforma das missões foi implementada em toda a costa brasileira, sendo sistematizada e justificada em duas correspondências escritas por Nóbrega: "Diálogo sobre a conversão do gentio" (1556) e "Plano civilizador" (1558). ${ }^{16}$ A superação do modelo civilizacional jesuítico deu-se com a política indigenista de D. José I e Pombal que, por meio de um conjunto de leis, não apenas expulsou os jesuítas do Brasil, mas criticou severamente a segregação dos índios em aldeias, mandando criar vilas ou povoados nesses estabelecimentos. O objetivo central do indigenismo ilustrado de Pombal era viabilizar, dentre outras medidas, os casamentos mistos entre índios e portugueses (miscigenação) e a equiparação política e jurídica dos índios e seus descendentes aos demais vassalos do rei ("nacionalização"). ${ }^{17}$

Embora esses dois grandes modelos civilizacionais tivessem muito em comum, eram vistos como antagônicos, pois desde as campanhas pombalinas contra a Companhia de Jesus, propagandeou-se a existência de uma oposição de interesses entre os jesuítas e o Estado, como se este quisesse a integração do índio à ordem social colonial, enquanto aqueles procuravam isolá-los nas aldeias, onde supostamente vigorava uma "teocracia" ${ }^{18}$ Diante desse quadro, os "Apontamentos" de Bonifácio ficam a meio caminho, procurando combinar, de forma conciliatória, algumas ideias centrais de Nóbrega e Pombal. Assim, Bonifácio recupera a importância da criação de aldeamentos como espaços de educação, civilização e catequese, mas também insiste na miscigenação e na "nacionalização" dos índios. Propõe uma espécie de segregação parcial e temporária dos índios nos aldeamentos, frisando ser a meta o fim das diferenças étnicas, sociais e políticas entre os "índios" e a "nação". Na conclusão dos "Apontamentos", no $44^{\circ}$ item, pode-se ler a seguinte orientação: 
Procurará com o andar do tempo, e nas aldeias já civilizadas, introduzir brancos e mulatos morigerados para misturar as raças, ligar os interesses recíprocos dos índios com a nossa gente, e fazer deles todos um só corpo da nação, mais forte, instruída e empreendedora $(. . .)^{19}$

Caberia ao Estado amparar os índios até a sua completa integração social e cultural. Além disso, a proposta de Bonifácio era bastante clara sobre o direito de os índios ascenderem na escala social à proporção que fossem educados e "civilizados", podendo ocupar cargos nas Câmaras de suas respectivas vilas, cursar o ginásio como pensionistas do Estado e ingressar nos colégios eclesiásticos para se ordenarem. ${ }^{20}$

As ideias de Bonifácio sobre os índios, seus direitos e deveres, embora não fossem novas ou revolucionárias, eram avançadas o suficiente para desagradar a elite agrária, ansiosa por ampliar os seus negócios e lucros mediante a apropriação territorial sem limites e restriçōes. Em outras palavras, não se tinha grande simpatia pelo indigenato, isto é, pelos direitos dos índios, especialmente o direito territorial assegurado pelas leis e pela jurisprudência colonial, e muito bem-lembrado por Bonifácio em seus apontamentos. Assim, o indigenismo de Bonifácio contribuía para isolá-lo ainda mais no cenário político pós-Independência. ${ }^{21}$

As convicções mais íntimas sobre os índios alimentadas por parte da elite agrária e escravista do Império ganharam expressão mais sistematizada um pouco depois, na conjuntura que marcou a discussão e a implementação da Lei de Terras, de 1850. Nesse momento, arvorando-se em porta-voz de correntes políticas com assento no Parlamento, Francisco Adolpho de Varnhagen defendeu a tese que os índios eram "selvagens" e capazes de perfectibilidade apenas quando impulsionados pelo uso da força, prescrevendo, sem rodeios, que eles não tinham direito à terra e que deveriam ser submetidos ao trabalho compulsório, para o bem da lavoura e o desenvolvimento do país. ${ }^{22}$

Em tom acusatório, Varnhagen qualificava de "filo-tapuias" todos que adotavam um ponto de vista favorável à inclusão dos índios no pacto político imperial, tocando no ponto mais crucial do debate indigenista do período. O incômodo de Varnhagen quanto ao fato de a geração da Independência e, pouco depois, de os românticos terem elegido o índio como um dos símbolos da nacionalidade era apenas o aspecto mais pitoresco da questão. ${ }^{23} \mathrm{O}$ que de fato preocupava Varnhagen, e estava em jogo no debate indigenista, desde a Independência, era qual o lugar político e social que os índios ocupariam no jovem Império do Brasil, isto é, seus direitos e obrigações. Quanto a isso, Varnhagen era absolutamente claro. No "Memorial Orgânico", publicado primeiramente em 1849/1850, ele afirmou:

Ora, os nossos Índios, ou são cidadãos brasileiros ou não: para serem não cumprem nenhuma das obrigações das leis, e andam vadiando e com as orelhas e beiços furados, em vez de serem guardas nacionais e vestir uniforme etc. Não sendo ou não estando nesse gozo, por incapacidade moral, como diz a constituição, não pode a lei - o direito civil - ver neles mais que uma gente estranha ao pacto social, que abusa da piedade que com eles se tem, não só por estarem nos matos e impossibilitarem que estes se transitem e se cultivem, mas até para darem assaltadas cruéis nas nossas fazendas suas vizinhas, que n'algumas partes se tem visto obrigadas a ceder-lhes o campo. As províncias em que há ainda muitos milhares deles, que são as do Pará, Mato Grosso e Goyazes, se não estão piores de que quando aboliram as bandeiras que lhe davam caça, estão talvez no mesmo estado (...) Mas o que diremos quando ainda na província do Espírito Santo, tão vizinha à do Rio de Janeiro, há Índios bravos? Conta certa exposição oficial que os Índios do Mocury gostam muito da carne dos negros, aos quais chamam de macacos do chão. E não é vergonha no meio de um país civilizado aturar tais canibais!?24

As ideias de Varnhagen, além de divergirem profundamente das de Bonifácio, também não eram novas, embora poucos ousassem proferi-las de forma tão pública. $\mathrm{Na}$ Assembleia Constituinte, o debate sobre o capítulo que definiria quem seriam os cidadãos do novo Império do Brasil antecipou algumas das objeções de Varnhagen, revelando aspectos importantes sobre o projeto político da geração da Independência sobre os índios. Nessa discussão, a reflexão sobre a "questão indígena" limitou-se ao debate se os índios poderiam ser considerados membros da sociedade brasileira e, por conseguinte, "cidadãos bra- 
sileiros", ou se, ao contrário, eram apenas habitantes do Brasil. Para o deputado Montezuma, ser "Brasileiro, é ser Membro da Sociedade Brasílica: portanto todo Brasileiro é Cidadão Brasileiro: convém sim dar a uns mais direitos, e mais deveres do que a outros; e eis aqui Cidadãos ativos, e passivos" ${ }^{25}$ Pouco depois explicou, com mais detalhes, quem fazia parte da "Sociedade Brasileira":

(...) falamos aqui dos Súditos do Império do Brasil, únicos que gozam dos cômodos de nossa Sociedade, e sofrem seus incômodos, que têm direitos, e obrigações no Pacto Social, na Constituição do Estado. Os Índios estão fora do grêmio da nossa Sociedade, não são súditos do Império, não o reconhecem, nem por consequência suas autoridades desde a primeira até a ultima, vivem em guerra aberta conosco, não podem de forma alguma ter direitos, porque não tem, nem reconhecem deveres ainda os mais simples, (falo dos não domesticados) logo: como considerá-los Cidadãos Brasileiros? Como considerá-los Brasileiros no sentido político? Não é minha opinião que sejam desprezados (...) Legislemos para eles; porém nesse sentido: ponhamos um capítulo próprio, e especial para isso em nossa Constituição; sigamos o exemplo dos Venezuelenses. Mas considerá-los já neste capitulo! Isto é novo. ${ }^{26}$

Montezuma, como outros homens de seu tempo, fazia uma clara distinção entre índios "bravos" e índios "domesticados", dando a entender que apenas os índios "bravos" ou "selvagens" não faziam parte da "sociedade" e nem eram "súditos" do Estado. Por isso, a inclusão dos índios ("bravos") no capítulo da Constituição que definiria quem seria considerado cidadão parecia-lhe não apenas algo muito novo, mas também absurdo. Contudo, as leis coloniais diziam bem ao contrário. A legislação pombalina, por exemplo, franqueou a todos os índios da América portuguesa a condição de súditos e vassalos, mesmo àqueles definidos como "bárbaros" que, supostamente, viviam "sem lei" e "sem religião" nas matas, florestas ou sertôes. ${ }^{27}$

Os índios "bárbaros" eram definidos pela Coroa, aliás, como súditos e vassalos "especiais", pois, tal como os órfãos e os miseráveis, tinham limitações socialmente reconhecidas e desfrutavam, por isso mesmo, de certos direitos privativos. ${ }^{28}$ No caso dos índios, o tratamento diferenciado se justificava precisamente pelo seu suposto grau zero ou, na melhor das hipóteses, "inferior" de civilização. Agindo assim, a Coroa impunha sua soberania às sociedades indígenas independentes e aos territórios conquistados, prescrevendo-lhes, em contrapartida, um conjunto de deveres e direitos que pacientemente deveria ser implementado.

Também os escravos foram excluídos da condição de cidadãos durante a discussão do assunto na Constituinte. Mas, a justificava assentou-se em outra ordem de argumento. De acordo com Montezuma, os motivos eram bem conhecidos por todos, pois os escravos eram "propriedade de alguém”, e assim tratados e reconhecidos pelas leis. Desse modo, perguntava: "como chamá-los brasileiros no sentido próprio? (...) Senhores, os escravos não passam de habitantes do Brasil". ${ }^{29}$ Outros, como o deputado França, preferiam fazer a distinção entre "brasileiros" e "cidadãos brasileiros", de acordo com a "qualidade da nossa população", mas reproduzindo a mesma lógica de exclusão de índios e escravos do pacto político e social. Assim, para o deputado, "os filhos dos negros, crioulos cativos, são nascidos no Território do Brasil, mas, todavia não são Cidadãos Brasileiros. Devemos fazer essa diferença: Brasileiro é o que nasce no Brasil, e Cidadão Brasileiro é aquele que tem direitos cívicos”. ${ }^{30}$ Quanto aos índios, argumentou:

Agora pergunto eu, um Tapuia é habitante do Brasil? É. Um Tapuia é nascido no Brasil? É. Um Tapuia é livre? É. Logo é cidadão brasileiro? Não, (...) pois os Índios no seu estado selvagem não são, nem se pode considerar como parte da grande família Brasileira; e são todavia livres, nascidos no Brasil, e nele habitantes. Nós, é verdade, que temos a Lei que lhes outorgue os Direitos de Cidadão, logo que eles abracem nosso costumes, e civilização, antes disso porém estão fora de nossa Sociedade. ${ }^{31}$

A exclusão dos tapuias - isto é, dos índios considerados "bravos", "selvagens" e até mesmo "inimigos" dos "civilizados" - e dos escravos da "classe de cidadãos", segundo o argumento de que não eram "brasileiros no sentido próprio", não era uma operação política fácil de ser feita. Como argumentou Keila Grinberg, o conceito de cidadania era polissêmico no período e, para "alguns deputados, cidadãos 
eram os indivíduos que tinham direitos, e era reconhecido por muitos que os escravos tinham direitos, principalmente o de serem protegidos pelo Estado". ${ }^{32}$ Se era difícil excluir os escravos e os libertos do pacto social que estava sendo costurado, mais ainda era fazer isso em relação aos índios, mesmo os tapuias. Afinal, eles eram autóctones, livres, e, mais ainda, desfrutavam, desde o período colonial, da condição de súditos e vassalos do Estado.

Se bem observado o projeto de Bonifácio e o debate constituinte, notar-se-á que a reflexão referiu-se, fundamentalmente, ao índio tido como "selvagem" ou "tapuia". A preocupação com os índios que viviam de forma independente em relação ao Império era justificável, pois pouco antes da Independência, em 1818, eles foram estimados em 800 mil indivíduos para uma população total calculada em 3,6 milhões de pessoas. ${ }^{33}$ Menos compreensível é a negligência da elite política imperial em relação aos índios "domesticados", contabilizados na população total do Império que, de acordo com o Censo de 1872, ainda representavam um contingente populacional importante. Em algumas províncias, como São Paulo e Minas Gerais, eles ultrapassavam a casa de 30 mil pessoas, enquanto que no Mato Grosso, Pará, Piauí e Espírito Santo os índios “domesticados” representavam parte importante da população total daquelas províncias. ${ }^{34}$

Qual seria o estatuto jurídico e político de uma população nominada e considerada indígena que não se confundia, contudo, com os índios "bravos", "tapuias" ou "selvagens"? Essa população indígena era considerada "civilizada" e parte da "sociedade brasileira", mas também não se confundia com os escravos, os libertos ou com os luso-brasileiros. A questão, embora importante e polêmica, não foi enfrentada de maneira direta pelo discurso político do período.

$\mathrm{Na}$ Constituição outorgada em 1824 havia um profundo silêncio sobre os índios em geral e seus direitos, pois em nenhum parágrafo eles foram citados nominalmente. ${ }^{35}$ Isso significou a ausência de um capítulo especial sobre a "civilização" dos índios "bravos", tal como esperava Bonifácio e outros constituintes. Tal questão, aliás, só seria retomada pelo Estado Imperial bem mais tarde, em 1845, quando o governo de D. Pedro II promulgou o "Regulamento das missōes de catequese e civilização dos índios" (Decreto no. 426, de 24 de julho de 1845), para lidar com a inconclusa tarefa de trazer os povos indígenas independentes para o "grêmio da civilização". ${ }^{36}$ Também não se fez nenhuma distinção entre "brasileiros" e "cidadãos brasileiros" no sentido de excluir os indígenas ("civilizados" ou "selvagens") do acesso à condição de cidadãos. Contudo, restringiu-se a cidadania à população livre, ficando os direitos políticos reservados aos "cidadãos ativos" definidos de acordo com critérios de renda. ${ }^{37}$

\section{Visões divergentes sobre a cidadania: terra, trabalho, liberdade e indianidade}

Apesar de a nova Constituição ignorar os índios e a questão indígena, o Primeiro Reinado desenvolveu uma política indigenista própria, distinguindo claramente, além disso, os índios "bravos" dos índios "civilizados", de acordo com o grau de integração à sociedade imperial prevalecente entre eles. Assim, enquanto os Botocudos do Espírito Santo receberam um regulamento especifico, ${ }^{38}$ recomendando seu aldeamento e civilização, já que eram "selvagens", os índios ("civilizados") da vila de Itaguaí, na província do Rio de Janeiro, foram considerados "cidadãos", orientando-se que as leis gerais do Império fossem aplicadas a eles. ${ }^{39}$

A política indigenista do Primeiro Reinado demonstra, portanto, uma clara disposição em considerar os índios "cidadãos", desde que eles fossem classificados como "civilizados". Mas como se verá a seguir, o conteúdo concreto da cidadania oferecida aos índios durante o governo de D. Pedro I esteve longe de ser a mesma usufruída pela "boa sociedade" ${ }^{40} \mathrm{e}$, mais que isso, daquela sonhada e reivindicada pelos próprios índios.

Os índios de Itaguaí pertenciam à antiga aldeia de São Francisco Xavier de Itinga, depois renomeada São Francisco Xavier de Itaguaí, fundada pelos jesuítas no início do século XVII, com índios Carijós da Lagoa 
dos Patos. Juntamente com as aldeias de São Lourenço, São Barnabé e São Pedro, a aldeia de Itaguaí foi um dos quatro mais importantes e duradouros aldeamentos da Companhia de Jesus no Rio de Janeiro. ${ }^{41}$

Entre o fim do século XVIII e o começo do XIX, a documentação coligida por Joaquim Norberto de Souza e Silva atesta que a aldeia de Itaguaí estava sofrendo sérias ameaças. Primeiramente, devido ao crescente desgaste e aos conflitos entre o administrador da fazenda Santa Cruz e o capitão-mor dos índios, que acabou gerando a expulsão dos índios de suas roças e sua dispersão. ${ }^{42}$ Após esses acontecimentos, o jovem índio José Pires Tavares foi recolhido e educado por Ignácio de Andrade Souto Mayor Rendon, aprendendo a ler, a escrever, além dos rudimentos do latim. Posteriormente, foi indicado pelo mesmo capitão Rendon para o cargo de capitão-mor dos índios. ${ }^{43}$ Data desse período o início da luta dos índios para reaverem suas terras, tal como fica registrado nas petições, requerimentos e atestados que o capitão-mor José Pires Tavares dirigiu à rainha D. Maria I, solicitando, dentre outras coisas, a:

(...) restituição da aldêa, com a igreja, paramentos, alfaias, casa do parocho, com tudo que n'ella havia; indemnisação de todas as perdas e danos; - fornecimento de sustento por um anno pela Fazenda Santa Cruz; - doação das terras que lhes foram assignadas pelos jesuítas para a sua aldêa, remidas do fôro, que a elles pagavam, concedendo-se-lhes novas terras para maior largueza e extensão às suas roças, lenhas, criaçōes e culturas; - confirmação da patente de capitão-mor que lhe passara o marquez de Lavradio, com soldo (...) ${ }^{44}$

O quanto desse pedido foi atendido não se sabe. Mas, o certo é que a aldeia de São Francisco Xavier de Itaguaí foi restituída aos índios e, ao seu lado, instalado o engenho de Itaguaí, impossibilitando a expansão da aldeia tal como desejava o capitão-mor. Poucos anos depois faleceu José Pires Tavares e, para piorar a situação, em 1806, o engenho foi vendido com a cláusula expressa de que os índios seriam removidos de sua aldeia, gerando novas disputas por terra. Parte dos índios foi transferida para uma localidade não especificada; outra ficou na aldeia, a despeito da ordem de remoção; e ainda outra, sem terra, migrou para a aldeia de Mangaratiba. Nesse período, os índios também tentaram ocupar as terras na ilha de Itacurussá (antiga Sapimiaguera), que haviam sido compradas pelos jesuítas, em 1718, em nome dos índios. Mas, a transferência da aldeia para lá foi tida como impraticável, pois as terras dos índios haviam sido arrendadas e julgou-se difícil tirar os foreiros, indenizando suas benfeitorias. ${ }^{45}$ Sabe-se também que, em 1812, outro índio da aldeia de Itaguaí, chamado Thomaz Lopes, requereu ao príncipe regente terras para criação. Como ele, os demais índios estavam sem terras. D. João procurou resolver a situação, expedindo aviso concedendo terras da fazenda Santa Cruz aos índios para que eles pudessem fazer suas plantaçôes coletivamente, mas indeferindo o pedido de Thomaz Lopes que queria terras para si. ${ }^{46}$ Além disso, o governo joanino criou, pouco depois, uma freguesia na aldeia de Itaguaí, que foi transformada em vila, em 1820.

Foi nessa conjuntura de crescente esbulho do patrimônio territorial dos índios de Itaguaí que, em setembro de 1824, o imperador D. Pedro I considerou "cidadãos" todos os índios residentes "na imperial fazenda de Santa Cruz ao pé da Vila de Itaguahy", 47 de acordo com a novíssima Constituição do Império. E justamente por serem cidadãos, deveriam pagar foro para permanecer nas terras da fazenda imperial, como qualquer outro indivíduo de igual posição e qualidade. ${ }^{48}$ Joaquim Norberto de Souza e Silva considerou isso mais um golpe baixo contra os índios, seu patrimônio e seus direitos, já que eles estavam sendo obrigados a pagar pelas terras recebidas de D. João VI. Também reconheceu que os índios ficaram "entusiasmados com o foro de cidadãos", ${ }^{49}$ não dando, contudo, atenção ao fato.

O entusiasmo dos índios por se tornarem "cidadãos" é muito revelador, no entanto, sobre os interesses sociais e políticos que eles acalentavam naquele tempo de mudança política. Assim, menos de dois anos depois da ordem do imperador, eram os próprios índios da vila de Itaguaí que reclamavam a condição de cidadãos, afirmando que estavam "livres de tutella, pelo tit. $2^{\circ}$, art. $6^{\circ}$ e $\$ 1^{\circ}$ da constituição política do império do Brazil [...]". ${ }^{50}$ Mais ainda, denunciavam e pediam providências contra os abusos de "seu excapitão-mór”, que além de não os deixar pagar os foros devidos, continuava praticando “(...) com elles a 
sua antiga autoridade e abusivo predomínio, determinando-os pelo mesmo teor em seus serviços, e extraordinárias diligências, como se fosse phantastica ou falsa aquella prestigiosa graça de liberdade (...)" ${ }^{51}$

A tutela foi, apesar das variações históricas, uma instituição muito presente na experiência social da população indígena e, mais que isso, um dos instrumentos legais mais utilizados para explorar o seu trabalho. O exemplo mais emblemático dos "desvios" que muitas vezes acompanhavam o exercício da tutela é a "administração particular", pesquisada por John Manuel Monteiro:

Assumindo o papel de administradores particulares de índios - considerados como incapazes de administrar a si mesmos -, os colonos [de São Paulo] produziram um artifício no qual se apropriaram do direito de exercer pleno controle sobre a pessoa e propriedade dos mesmos sem que isso fosse caracterizado juridicamente como escravidão. ${ }^{52}$

Equiparados aos miseráveis e aos órfãos, os índios foram tidos, em diferentes momentos, como incapazes de se autogovernarem, prevendo-se, por isso mesmo, o exercício da tutela, tanto sobre suas pessoas como sobre os seus bens e o seu comércio. ${ }^{53}$ Padres, moradores, juízes de órfãos, capitães-mores e diretores de índios foram alguns dos tutores ou dos responsáveis pelos índios mais frequentes e também aqueles que tiveram melhores condições de controle sobre seu trabalho. Sob o estatuto da tutela, portanto, não poucas vezes, formas mal disfarçadas de cativeiro eram legitimadas e permitidas.

Quanto ao pagamento de foro, se as leis fossem observadas, os índios não deveriam ser obrigados a nenhum desembolso. Afinal, eles foram expulsos de terras que haviam recebido de forma legítima no século XVII e era mais uma arbitrariedade fazê-los pagar foro pelas novas terras recebidas de D. João, a título de reparo, e que, pela negligência do próprio Estado, não estavam totalmente regularizadas. Mais ainda, fazer com que índios pagassem foro pelas terras que ocupavam era uma ruptura significativa em relação à jurisprudência colonial. Pois, não pagar foro pelas terras ocupadas e nem ser transferidos de tais terrenos, mesmo quando as terras fossem concedidas na forma de sesmarias a alguém, era uma prerrogativa dos índios garantida pelo princípio do indigenato, que o Alvará de $1^{\circ}$ de abril de 1680 fez questão de salientar. ${ }^{54}$

Neste episódio, fica bastante configurado que os índios se apropriaram da categoria de cidadãos e trataram de organizar sua própria agenda política. Afinal, o modo como eles reivindicaram a qualidade de cidadão e o sentido que atribuíram a sua nova identidade política não coincidia com a do Estado Imperial. Concretamente, D. Pedro I impôs aos índios a perda de antigos direitos em nome de novos deveres e obrigações. Os índios procuraram reverter esse quadro de prejuízos se apropriando do vocabulário político da época e do "outro", de acordo com seus próprios interesses e objetivos.

Eles agiram segundo uma lógica bastante própria, correlacionando os novos deveres (pagamento de foro) com novos direitos (o fim da tutela). Mostraram-se, é verdade, receptivos ao pagamento de foro e, até mesmo, exigiram o "direito" de poderem cumprir tal "dever" e "obrigação". Mas, só agiram desse modo porque enxergaram no horizonte a "prestigiosa graça da liberdade" que a condição de cidadãos lhes poderia garantir, isto é, o fim da tutela, desdobrando a questão da cidadania para campos e situações não previstas, talvez, por D. Pedro I, no momento quando se decidiu por aquele despacho.

O episódio também ajuda a entender certos meandros das relações interétnicas tecidas no processo de gestação da "nação brasileira". A identidade étnica é um fenômeno relacional e, como demonstrou Barth, pode ser reproduzida, ou não, de acordo com as circunstâncias históricas e sociais. ${ }^{55} \mathrm{Na}$ conjuntura pós-Independência, o Estado imperial estimulou a dissolução da identidade étnica dos índios (i. e., "índios aldeados" ou "índios de Itaguaî") em nome de outra: a identidade política de "cidadão". Essa é uma questão importante, pois, nos processos de construção, reprodução ou dissolução das identidades (étnicas ou políticas), o Estado costuma exercer um papel importante, baseado no poder de atribuir aos indivíduos ou aos grupos sociais direitos e deveres que podem reforçar, ou não, determinadas identidades e classificações sociais e políticas. ${ }^{56}$ 
Assim, personificado na figura do imperador, o Estado assumiu o discurso e o projeto político de assimilação social e política dos índios ao nominá-los de "cidadãos", fazendo a eles duas imposições: as leis mais gerais do Império, inerentes à condição de cidadão, atribuindo-lhes uma nova identidade política, bem como novos deveres, obrigações e direitos; e o fim dos privilégios e direitos vinculados à legislação indigenista e à identidade indígena (indigenato) que eram assegurados pela Coroa portuguesa no Antigo Regime colonial. Em poucas palavras, o Estado procurou acabar com a identidade étnica dos índios - isto é, a de índios aldeados - em nome de outra, a de "cidadãos", mais abrangente e vinculada ao projeto nacional, mas não garantindo aos índios o direito de propriedade das terras que ocupavam e das quais eram legítimos possuidores.

A condição subalterna dos índios também está perfeitamente ilustrada nos acontecimentos ocorridos em Itaguaí. Em uma das últimas notícias que se tem sobre eles, de 1834, o juiz de órfãos João José Figueira informou ao presidente da província do Rio de Janeiro que, depois de os índios perderem a propriedade e os rendimentos das terras da ilha de Sapimiaguera, compradas pelos jesuítas em nome dos índios, eles estavam cultivando as terras recebidas de D. João VI, mas que permaneciam como propriedade da nacional fazenda de Santa Cruz. Informou ainda que, desde então, os índios viviam desse modo,

(...) sem que a conservatória entrasse nunca no conhecimento d'estes bens, por serem de propriedade nacional, e menos hoje se poderia entrar em tal averiguação por estar extincto o nome d'esta aldeia e se acham os índios que a ela pertenciam, com praça na guarda nacional, tanto em uma como em outra arma, e só os menores e velhos é que d'ella estão excusos; e por tal motivo já não são considerados sinão como guardas nacionaes, e não como índios aldeados. ${ }^{57}$

O alistamento dos índios na Guarda Nacional é uma informação importante. A criação da corporação ocorreu em 1831 e tinha como um de seus pilares o princípio do "cidadão armado", pronto a defender a nação. A base do alistamento era o município e seus membros eram convocados para realizarem uma série variada de serviços públicos locais e sempre que as forças policiais se mostrassem incapazes de garantir a ordem contra rebeliôes e outras desordens. Para usufruir os direitos políticos da cidadania e ingressar na Guarda Nacional, a constituição de 1824 determinava um rendimento mínimo modesto, de 100 mil-réis ao ano, mas que parece ter sido suficiente para excluir uma parcela da população pobre e livre do direito de ser eleitor e votar.

O alistamento dos índios na Guarda Nacional incita certas especulações. Pois, como observou José Murilo de Carvalho, milicianos e votantes eram virtualmente os mesmos indivíduos. ${ }^{58} \mathrm{~A}$ partir desse dado pode-se formular a hipótese de que os índios não apenas serviam na Guarda Nacional, como atesta a documentação, mas também participavam dos processos eleitorais, exercendo a cidadania de forma mais abrangente, positiva e ativa. Mais ainda, existia uma hierarquização da população pobre e livre imperial, verificável principalmente nos processos de recrutamento para o serviço militar no Exército e na Armada, quando eram selecionados indivíduos "sem honra", isto é, homens classificados pelas autoridades como "delinquentes", "desordeiros" e/ou "vadios". Assim, pode-se especular que os índios não se confundiam com a população pobre e livre que não estava habilitada a votar, nem tampouco ao serviço na Guarda Nacional, e que acabava caindo, por isso mesmo, nas malhas do serviço militar compulsório. Desse ângulo, a transformação dos índios em guardas nacionais sinalizaria que eles, depois da Independência e mesmo sendo pobres, estariam ocupando um lugar de relativa honra na escala social e potencialmente exercendo uma cidadania ativa no cenário político eleitoral.

Tudo isso, contudo, são especulaçôes. Mais ainda, apesar da Guarda Nacional ser uma "milícia cidadã", não se deve superestimar a participação nela como indicativo de que os índios de Itaguaí gozavam, no início do Império, dos direitos e prerrogativas dos cidadãos ativos e tampouco dos privilégios que o costume reservava aos cidadãos pobres, porém "honrados". Pois é bem sabido que os serviços prestados à Guarda Nacional não eram remunerados, exigindo dos praças e do oficialato a continuidade de suas atividades econômicas e ofícios para prover a própria existência e de seus dependentes. 
A remuneração só estava prevista quando se destacava o indivíduo para cumprir tarefas longe de sua municipalidade e por um longo período de tempo. Era notório que o serviço litúrgico prestado na Guarda Nacional podia comprometer as atividades econômicas e ocupacionais tanto dos oficiais como dos milicianos. Tornou-se comum, por isso mesmo, as tentativas de evadir-se do cumprimento dos serviços devidos à Guarda Nacional, que terminavam recaindo nos setores sociais mais pobres e desprotegidos dos distritos. ${ }^{59}$

Joaquim Norberto de Souza e Silva interpretou o documento escrito pelo juiz como um testemunho importante, utilizando-o como um marco histórico sinalizador do "fim da aldeia de Itinga", ${ }^{60}$ interrompendo nessa data sua narrativa histórica sobre os índios de Itaguaí. Não se deve confundir, no entanto, o fim da existência jurídica de uma aldeia com o fim de um grupo social que partilhava uma história e uma identidade comum e, menos ainda, com o desaparecimento físico dos índios. Os índios e a comunidade indígena não desapareceram e, ao que tudo indica, em 1834, eles ainda estavam cultivando as terras recebidas por D. João VI, até porque os índios guardas nacionais, as crianças pequenas, as mulheres e os velhos precisavam garantir o sustento e a própria vida. A narrativa do juiz não fala de morte, desaparecimento ou migração da população indígena. Ao contrário, afirma que eles estavam lá, bem vivos, servindo como guardas nacionais, com exceção dos velhos, crianças e, como não poderia deixar de ser, também das mulheres.

O que o documento nos permite perceber, portanto, não é o desaparecimento físico dos índios, mas a mudança radical do estatuto jurídico daquela população, que deixava de ser vista e considerada como “índios aldeados”, para transformar-se em "cidadãos”, já que só os cidadãos poderiam ser guardas nacionais. Além disso, neste episódio de 1834 , fica bem claro que o juiz se recusou a regularizar a situação das terras dos índios, segundo a justificativa de que eles não eram mais índios aldeados. Eles tinham se tornado guardas nacionais e estavam alistados em duas armas. Perderam, por isso, o direito às terras que ocupavam na qualidade de índios. Em outras palavras, ao transitarem para a condição de cidadãos, os índios tornaram-se, aos olhos do juiz, guardas nacionais sem direito a terra!

Não é demais lembrar que, até 1832, a administração dos bens dos índios era da alçada dos ouvidores das comarcas, que eram também os conservadores dos índios. ${ }^{61} \mathrm{O}$ decreto de 3 de junho de 1833 transferiu a administração dos bens dos índios para a alçada dos juízes de órfãos das respectivas municipalidades. ${ }^{62}$ Assim, vindo de quem deveria zelar pelos bens dos índios, o desinteresse do juiz de órfãos em averiguar e garantir os direitos e as propriedades dos índios de Itaguaí, presente nos argumentos por ele mesmo apresentados, só pode ser qualificado como uma improbidade. Aliás, o próprio presidente provincial reconheceu e lamentou, pouco depois, em 1836, o descaso dos juízes de órfãos em zelarem pelos interesses e patrimônio dos índios. ${ }^{63}$

Importante notar, além disso, que o ofício do juiz de órfão instaura um insidioso discurso de precarização da relação do índio com seu patrimônio territorial, vinculando seus direitos de posse e propriedade a uma indianidade que só seria acessível aos indivíduos residentes em aldeamentos reconhecidos pelo Estado. Esse argumento do juiz de órfãos não tinha base legal, pois inexistia legislação que indicasse que a atribuição dos direitos de cidadãos aos índios tivesse como contrapartida a ab-rogação do direito sobre o patrimônio conseguido durante o Antigo Regime colonial. Apesar disso, a argumentação do juiz atendia aos interesses de todos aqueles que cobiçavam as terras indígenas, em um contexto histórico e social caracterizado por uma acirrada disputa pela terra na região de Itaguaí.

A recusa do juiz de órfãos em regularizar o patrimônio territorial dos índios pode ser considerado um passo importante no sentido de expropriá-los definitivamente da propriedade de suas terras. Afinal, àquela altura, os índios viviam na terra de forma precária, sem garantias formais e políticas de permanência naqueles terrenos. Visto desse ângulo, os acontecimentos de Itaguaí demonstram que aqueles índios experimentaram o significado mais concreto de ser cidadão do novo Império do Brasil, a partir de duas situações fundamentais: prestando serviços ao Estado em obras e funções públicas, como guar- 
das nacionais; ${ }^{64}$ e ingressando nos limites da precariedade que caracterizavam a vida de uma população rural livre, pobre e sem garantias formais de posse e propriedade territorial. ${ }^{65}$

A prestigiosa graça da liberdade que a condição de cidadão acenava mostrou-se quimera para os índios, pois a transição da condição de "índios" para a de "cidadãos" fazia-se à custa do esquecimento de direitos historicamente construídos, sobretudo em relação às terras que eles ocupavam e das quais tinham títulos legítimos, tornado precária a posse, a permanência e a propriedade territorial. Mais ainda, trocava-se a antiga autoridade e tutela exercida pelos capitães-mores de ordenança pela nova autoridade dos oficiais da Guarda Nacional e dos juízes de paz que, ao que tudo indica, passaram a controlar, organizar e explorar a força de trabalho dos índios de Itaguaí.

\section{Considerações finais}

Para parte significativa da elite imperial, não resta dúvida que a identidade de "cidadão" deveria ser um privilégio de poucos e cumprir a mesma função que a antiga identidade portuguesa exercera na sociedade colonial, isto é, demarcar a diferença e a distância entre as elites e os setores subalternos da sociedade, formados por escravos, negros, índios, libertos e mestiços. ${ }^{66}$ No entanto, a Constituição não assegurou a condição de cidadão apenas à boa sociedade.

Coube à prática política e social do período a reversão da tendência liberal e democratizante do texto constitucional. Nesse processo, o Estado exerceu papel importante, assegurando a reprodução das hierarquias sociais que vigoraram no período colonial, transformando os "direitos" inerentes à cidadania, de fato, em privilégio de poucos, ao mesmo tempo em que impôs os "deveres" da nação à "população" do Império. Apesar disso, não é irrelevante tentar compreender como os diferentes extratos da sociedade e da população aprenderam e buscaram alargar a concepção estreita de cidadania que vigorou na práxis política e social do Império. Pois, como sublinhou José Murilo de Carvalho, "o cidadão político não nasceu adulto em lugar nenhum, exigiu período de aprendizado, mais ou menos longo ou mais curto, dependendo do país" ${ }^{67}$

Algumas conclusões gerais podem ser tiradas, a partir do episódio narrado e analisado neste texto, sobre as relações de poder entre os índios e o Estado durante o processo inicial de formação da nacionalidade brasileira. Em primeiro lugar, no Brasil oitocentista, é uma simplificação reduzir a população indígena aos membros das sociedades tribais que viviam de forma relativamente independente do governo imperial. Afinal, também existiam diversos indivíduos e diversas comunidades que se percebiam e eram percebidos simultaneamente como parte da sociedade e como índios. Em segundo, a condição subalterna dos índios não os impedia, necessariamente, de agir politicamente na nova conjuntura institucional instaurada pelo processo de Independência. Ao contrário, eles souberam mobilizar a favor de seus interesses até mesmo o discurso político e ideológico de seus interlocutores, apropriando-se e dando significado próprio ao conceito de "cidadãos" do Império.

Finalmente, é importante frisar que o Primeiro Reinado adotou um discurso e uma prática de assimilação da população indígena bem ao gosto do pensamento político do século XIX, que imaginava as naçôes como entidades políticas, sociais e culturais "unas e indivisas" ${ }^{68} \mathrm{Fez}$ isso, contudo, impondo aos índios de Itaguaí apenas os novos deveres e obrigações inerentes à condição de cidadãos. Em outras palavras, eles foram destituídos das garantias legais de posse e uso das terras que ocupavam, perdendo, diante das autoridades do Estado, o status de índios "aldeados" e os direitos vinculados ao indigenato, e sendo progressivamente reclassificados como cidadãos e guardas nacionais sem terra própria.

Apesar disso, não se deve concluir, baseado no episódio, que os índios da vila de Itaguaí "desapareceram", ou perderam sua identidade étnica, como em um passe de mágica. Não resta dúvida que as condições materiais de reprodução social do grupo estavam cada vez mais abaladas devido à crescente dificuldade de eles permanecerem na terra de forma coletiva e estável. Mas, a despeito de todas essas dificuldades, é importante notar que eles também possuíam uma cultura política bastante sólida, 
construída, aprendida, transmitida e praticada ao longo da história como índios aldeados e súditos da Coroa portuguesa. ${ }^{69} \mathrm{E}$ foi justamente esse capital político que eles mobilizaram quando peticionaram ao Estado Imperial o fim da tutela e a prestigiosa graça da liberdade que a condição de cidadãos prometia, procurando transitar da antiga condição de súditos e vassalos da Coroa portuguesa para o novo status de cidadãos do Império do Brasil.

\section{Notas}

${ }^{1}$ Este artigo é resultado de pesquisa que conta com o apoio da Fundação Carlos Chagas de Amparo à Pesquisa do Estado do Rio de Janeiro (FAPERJ).

${ }^{2}$ Para um balanço sobre José Bonifácio, ver COSTA, Emília Viotti da. José Bonifácio: mito e história. In: Da Monarquia à República: momentos decisivos. São Paulo: Grijalbo, 1977, p. 53-108; e RIBEIRO, Gladys Sabina. Nação e cidadania no jornal O Tamoio. Algumas consideraçôes sobre José Bonifácio, sobre a Independência e a Constituinte de 1823. In: RIBEIRO, Gladys Sabina (Org). Brasileiros e Cidadãos. São Paulo: Alameda, 2008. p. 37-64.

3 "Regulamento para a civilização dos índios botocudos nas margens do rio Doce - Portaria". In: OLIVEIRA, José Joaquim Machado de. Notas, apontamentos e notícias para a história da província do Espírito Santo. Revista do Instituto Histórico e Geográfico do Brazil, t. XIX, no 22, p. 161-348, 1856. p. 221-224.

${ }^{4}$ SILVA, José Bonifácio de Andrada e. Apontamentos para a civilização dos índios bravos do Império do Brasil. In: CALDEIRA, Jorge (Org). José Bonifácio de Andrada e Silva. São Paulo: Ed. 34, 2002. p. 183-199.

${ }^{5}$ MOREIRA NETO, Carlos de Araújo. Os Índios e a Ordem Imperial. Brasília: CGDOC/Funai, 2005. p. 247.

${ }^{6}$ CUNHA, Manuela Carneiro da. Política indigenista no século XIX. In: CUNHA, Manuela Carneiro da (Org.). História dos Índios no Brasil. São Paulo: Companhia das Letras, 1992, p. 133-154. p.138.

${ }^{7}$ SILVA, José Bonifácio de Andrada e. Op. cit., p. 184.

${ }^{8}$ Idem, p. 187.

${ }^{9}$ Idem, p. 186-187. Sobre os índios do Brasil no repertório das ideias do século XVIII, $c f$. Melo Franco, Afonso Arinos de. O Índio Brasileiro e a Revolução Francesa - As Origens Brasileiras da Teoria da Bondade Natural. 3. ed. Rio de Janeiro: Topbooks, sd.

${ }^{10}$ SILVA, José Bonifácio de Andrada e. Op. cit., p. 191.

${ }^{11}$ Idem, p. 188.

${ }^{12}$ Idem, p. 190.

${ }^{13}$ Idem, p. 193.

${ }^{14}$ Idem, p. 183 e 194.

${ }^{15} \mathrm{Idem}$, p. 191.

${ }^{16}$ Ver EISENBERG, José. As Missões Jesuiticas e o Pensamento Politico Moderno. Belo Horizonte: Editora da UFMG, 2000. p. 91.

${ }^{17}$ Sobre o corpo legislativo referente aos índios durante a administração pombalina, ver Domingues, Ângela. Quando os Índios eram Vassalos. Colonização e Relações de Poder no Norte do Brasil na Segunda Metade do Século XVIII. Lisboa: Comissão Nacional para as Comemoraçôes dos Descobrimentos Portugueses, 2000. p. 25-51.

${ }^{18}$ É bem conhecido o papel estratégico dos aldeamentos e missões, especialmente os jesuíticos, para a segurança dos enclaves coloniais contra os ataques de índios inimigos, as insurreiçôes de escravos e os ataques de estrangeiros e quilombolas. Cf. ALENCASTRO, Luiz Felipe de. O trato dos viventes. São Paulo: Companhia das Letras, 2000. p. 123-124. Apesar disso, a política pombalina passou a considerar as missões jesuíticas como uma ameaça aos interesses portugueses, simplificando as relaçôes historicamente constituídas entre a Companhia de Jesus e a Coroa. Cf. MAXWELL, Kenneth. Marques de Pombal: paradoxo do iluminismo. 2.ed. Rio de Janeiro: Paz e Terra, 1996. p. 54.

${ }^{19}$ SILVA, José Bonifácio de Andrada e. Op. cit., p.198.

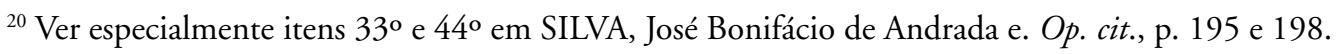

${ }^{21}$ Como observou Emília Viotti, as ideias de Bonifácio sobre a mulher, a liberdade religiosa, a gradual emancipação dos escravos e o uso racional e produtivo das terras fez com que ele perdesse "rapidamente o apoio dos proprietários de terras e dos altos comerciantes". Cf. COSTA, Emília Viotti da. Op. cit., p. 71.

${ }^{22}$ VARNHAGEN, Francisco Adolpho de. Os Índios Bravos e o Sr. Lisboa, Timon 30. Lima: Imprensa Liberal, 1867. p. 52.

${ }^{23}$ Sobre o culto à natureza e ao índio como elementos centrais na formulação do nacionalismo romântico no Brasil, ver COUTINHO, Afrânio. A Literatura no Brasil - Era Romântica. 6.ed. São Paulo: Global, 2002. p. 24. Sobre a versão sacrificial do indianismo, ver BOSI, Alfredo. Um mito sacrificial: o indianismo de Alencar. In: BOSI, Alfredo. Dialética da Coloni- 
zação. 4. ed. São Paulo: Companhia das Letras, 2001. p. 176-193. Sobre a tentativa de Varnhagen de invalidar os argumentos românticos em defesa dos índios, negando-lhes o estatuto de população autóctone, ver CEZAR, Temístocles. A retórica da nacionalidade de Varnhagen e o mundo antigo: o caso da origem dos tupis. In: GUIMARÃES, Manoel Luiz Salgado (Org.). Estudos sobre a Escrita da História. Rio de Janeiro: 7Letras, 2006. p. 29-41.

${ }^{24}$ VARNHAGEN, Francisco Adolpho de. Memorial orgânico. In: MOREIRA NETO, Carlos de Araújo. Os Índios e a Ordem Imperial. Brasília: CGDOC/Funai, 2005. p. 338.

${ }^{25}$ Diário da Assembleia Geral Constituinte, e Legislativa do Império do Brasil, Seção de 23 de setembro de 1823 , p. 90. Disponível em <http//imagem.camara.gov.br/dc_20a.asp?selCodColecaoCsv=c\&Datain=23/9/1823>. Acesso em 23 out. 2009. Nesta e em outras citações do mesmo corpo documental, optou-se pela modernização ortográfica, respeitando, contudo, as ênfases, as expressões de época e a pontuação.

${ }^{26}$ Ibidem.

${ }^{27}$ ALMEIDA, Ver Maria Regina Celestino de. Metamorfoses Indígenas - Identidade e Cultura nas Aldeias Coloniais do Rio de Janeiro. Rio de Janeiro: Arquivo Nacional, 2003. p. 105. Ver também DOMINGUES, Ângela. Op. cit., p. 25-62.

${ }^{28}$ DOMINGUES, Ângela. Op. cit., p. 43.

${ }^{29}$ Diário da Assembleia Geral Constituinte, e Legislativa do Império do Brasil, Seção de 23 de setembro de 1823, p. 109. Disponível em <http//imagem.camara.gov.br/dc_20a .asp?selCodColecaoCsv=c\&Datain=23/9/1823>. Acesso em 13 out. 2009.

${ }^{30}$ Idem, p. 90.

${ }^{31}$ Ibidem.

${ }^{32}$ Cf. GRINBERG, Keila. O Fiador dos Brasileiros - Cidadania, Escravidão e Direito Civil no Tempo de Antônio Pereira Rebouças. Rio de Janeiro: Civilização Brasileira, 2002. p. 110-111.

${ }^{33}$ Cf. OLIVEIRA, João Pacheco de. Ensaios em Antropologia Histórica. Rio de Janeiro: Editora UFRJ, 1999. p. 142.

${ }^{34}$ Idem, p. 138.

${ }^{35}$ Cf. MOREIRA NETO, Carlos de Araújo. Op. cit., p. 247.

${ }^{36}$ Para uma análise desse corpo legal, ver MOREIRA NETO, Carlos de Araújo. Op. cit., p. 254-257.

${ }^{37}$ Para um balanço da cidadania no Brasil oitocentista, ver CARVALHO, José Murilo de. Cidadania: tipos e percursos. Revista Estudos Históricos, no. 18, p. 1-21, 1996.

38 "Regulamento para a civilização dos índios botocudos nas margens do rio Doce - Portaria de 28 de janeiro de 1824". In: OLIVEIRA, José Joaquim Machado de. Op. cit, p. 221-224.

${ }^{39}$ Portaria de 9 de Setembro de 1824. In: SILVA, Joaquim Norberto de Souza e. Memória histórica e documentada das aldeias de índios da província do Rio de Janeiro. Revista do Instituto Histórico e Geográfico do Brazil, t. XVII, $3^{\mathrm{a}}$. Série, nº. 14, p. 108-552, 1854, p. 412.

${ }^{40}$ De acordo com Ilmar Mattos, só a "boa sociedade" conjugava em si os principais atributos que organizavam as hierarquias sociais do Império: a liberdade e a propriedade. Cf. MATTOS, Ilmar Rohloff de. O Tempo Saquarema. A Formação do Estado Imperial. São Paulo: Hucitec, 1990. p. 115.

${ }^{41}$ ALMEIDA, Maria Regina Celestino de. Op. cit., p. 87.

${ }^{42}$ SILVA, Joaquim Norberto de Souza e. Op. cit, p. 186.

${ }^{43}$ ALMEIDA, Maria Regina Celestino de. Op. cit., p. 239.

${ }^{4}$ SILVA, Joaquim Norberto de Souza e. Op. cit., p. 180.

${ }^{45}$ Idem, p. 190-193.

${ }^{46}$ Aviso régio de 24 de outubro de 1824 [sic1812] permitindo dar terras da fazenda de Santa Cruz para a cultura dos índios da aldeia de Itaguay. In: SILVA, Joaquim Norberto de Souza e. Op. cit., p.382.

${ }^{47}$ Portaria de 9 de Setembro de 1824. In: SILVA, Joaquim Norberto de Souza e Op. cit., p. 412.

${ }^{48}$ Portaria de 9 de Setembro de 1824. In: SILVA, Joaquim Norberto de Souza e. Op. cit., p. 413.

${ }^{49}$ SILVA, Joaquim Norberto de Souza e. Op. cit., p. 193.

50 “Requerimento dos índios de Itaguahy”. In: SOUZA E SILVA, Joaquim Norberto de. Op. cit., p. 413.

${ }^{51}$ Idem.

${ }^{52}$ MONTEIRO, John Manuel. Negros da Terra: índios e bandeirantes nas origens de São Paulo. São Paulo: Companhia das Letras, 1994. p. 137.

53 DOMINGUES, Ângela. Op. cit., p. 43.

${ }^{54}$ De acordo com o Alvará de 1 de abril de 1680, “(...) na concessão de sesmarias se reserva sempre o prejuízo de terceiros, e muito mais se entende, e quero que se entenda, ser reservado o prejuízo e o direito dos índios, primários e naturais senho- 
res dellas." Cf. MENDES JÚNIOR, J. Os Indígenas do Brasil, seus Direitos Individuais e Políticos. São Paulo: Typographia Hennies Irmãos, 1912. p. 35.

${ }_{55}$ BARTH, Fredrik. Grupos étnicos e suas fronteiras. In: POUTIGNAT, Philippe \& STREIFF-FENART, Jocelyne. Teorias da Etnicidade. São Paulo: Fundação Editora da Unesp, 1998, p. 185-128. p. 209.

${ }^{56}$ Como explica José Maurício Arruti, a "nominação oficial” pode ser definida como um processo "de instituição de uma categoria jurídica ou administrativa que, englobando uma população heterogênea com base em determinadas características comuns, a institui como sujeito de direitos e deveres coletivos, ao mesmo tempo como objeto de ação do Estado". Cf. ARRUTI, José Maurício. Mocambo: antropologia e história do processo de formação quilombola. Bauru/SP: Edusc, 2006. p. 52.

${ }^{57}$ Apud SILVA, Joaquim Norberto de Souza e. Op. cit., p.194.

${ }^{58}$ CARVALHO, José Murilo de. Dimensiones de la ciudadanía em el Brasil del siglo XIX. In: SABATO, Hilda (Coord). Ciudadanía política y formación de las naciones. Perspectivas históricas de América Latina. México: FCE, COLMEX, FHA, 1999. p. 333.

${ }^{59}$ Sobre a cooperação litúrgica prestada pelos guardas nacionais ao Estado, os tipos de serviços realizados e o funcionamento da corporação, ver URICOECHEA, Fernando. O Minotauro Imperial. A Burocratização do Estado Patrimonial Brasileiro no Século XIX. Rio de Janeiro/São Paulo: Difel, 1978. Sobre o peso desse serviço entre setores mais pobres, cf. p. 204.

${ }^{60}$ SILVA, Joaquim Norberto de Souza e. Op. cit., p.194.

${ }^{61}$ Sobre as autoridades que tutelavam o patrimônio dos índios, ver CUNHA, Manuela Carneiro da. Prólogo. In: CUNHA, Manuela Carneiro da (Org.). Legislação Indigenista no Século XIX. São Paulo: Edusp, 1992, p. 1-34. p. 14.

${ }^{62}$ 03/06/1833: Decreto - Encarrega da administração dos bens dos Índios, aos juízes de órfãos dos municípios respectivos. In: CUNHA, Manuela Carneiro da (Org.). Op. cit., p. 156.

${ }^{63}$ Rio de Janeiro (província). Presidente (Soares de Souza). Relatório de 18 de outubro de 1836. Disponível em <http://brazilcrl.edu/bsd/bsd/u815/000008.html>. p. 8 .

${ }^{64}$ A prestação de serviços ao Estado como um dos significados mais concretos da cidadania para os pobres livres do Império foi analisada por José Murilo de Carvalho, em Cidadania: tipos e percursos. Op. cit. Em direção paralela, o estudo de Beatriz Mamigonian mostra que também os africanos livres ficaram sujeitos ao Estado Imperial, prestando diferentes serviços. Cf. MAMIGONIAN, Beatriz. A harsh and gloomy fate. Liberated Africans in the service of the Brazilian State, 1830s-1860s. In: CURRY, Dawne; DUKE, Eric \& Smith, MARSHANDA (Ed.). Extending the Diaspora. New Histories of Black People. Urabana/Chicago: University of Illinois Press, s/d., p. 22-45. Sobre a requisição de índios para a prestação de serviços ao Estado, incluindo o Exército e a Armada, ver CUNHA, Manuela Carneiro da. Prólogo. Op. cit., p. 1-34; e MOREIRA, Vânia Maria Losada. Caboclismo, vadiagem e recrutamento militar de índios na província do Espírito Santo (1822-1875). Diálogos Latinoamericanos, n. 11, p. 94-120, 2005.

${ }^{65}$ Já foi devidamente demonstrado que o processo histórico de organização do mercado de trabalho livre durante o Império e a Primeira República se fez à custa do cativeiro da terra. Cf. MARTINS, José de Souza. O Cativeiro da Terra. 6.ed. São Paulo: Hucitec, 1996, especialmente a primeira parte. Sobre a precariedade como um dos elementos definidores da condição de vida e trabalho dos livres e pobres do Império, ver LIMA, Henrique Espada. Sob o domínio da precariedade: escravidão e os significados da liberdade de trabalho no século XIX. Topoi, v. 6, n. 11, p. 289-326, jul.-dez. 2005. p. 292.

${ }^{66}$ Como argumentaram István Jancsó e João Paulo Pimenta: "Não era simples para as elites luso-americanas despirem-se de algo tão profundamente arraigado como a identidade portuguesa, expressão sintética de sua diferença e superioridade diante dos muitos para quem essa posição estava fora de alcance. Saberem-se portugueses constituía o cerne da memória que esclarecia a natureza das relaçôes que mantinham com o restante do corpo social nas suas pátrias particulares, aquela massa de gente de outras origens com a qual, sobre a qual ou contra a qual caberia organizar o novo corpo político." Cf. JANCSÓ, István \& PIMENTA, João Paulo. Peças de um mosaico (ou Apontamentos para o estudo da emergência da identidade nacional brasileira). In: MOTA, Carlos Guilherme (Org.). Viagem Incompleta. A Experiência Brasileira (1500-2000). São Paulo: Editora Senac, 1999, p. 127-175. p. 173.

${ }^{67}$ CARVALHO, José Murilo de. Cidadania: tipos e percursos. Op. cit., p. 6.

${ }^{68}$ Como observou Hobsbawm, o nacionalismo veio antes das nações, criando-as simbolicamente e instituindo a ideia ou a equação, segundo a qual "nação = Estado = povo". Pior ainda, a nação passou a ser definida como uma realidade "uma e indivisível”. Cf. HOBSBAWM, Eric. Naçôes e Nacionalismos desde 1780. Rio de Janeiro: Paz e Terra, 1990. p. 31-32.

${ }^{69}$ ALMEIDA, Maria Regina Celestino de. O lugar dos índios na história entre múltiplos usos do passado: reflexões sobre cultura histórica e cultura política. In: SOIHET, Rachel; ALMEIDA, Maria Regina Celestino de; AZEVEDO, Cecília; GONTIJO, Rebeca (Orgs). Mitos, Projetos e Práticas Políticas. Rio de Janeiro: Civilização Brasileira, 2009, p. 201-230. p. 209. 


\section{Referências bibliográficas}

ALENCASTRO, Luiz Felipe de. O trato dos viventes. A formação do Brasil no Atlântico Sul. São Paulo: Companhia das Letras, 2000.

ALMEIDA, Maria Regina Celestino. O lugar dos índios na história entre múltiplos usos do passado: reflexões sobre cultura histórica e cultura política. In: SOIHET, Rachel;

ALMEIDA, Maria Regina Celestino de; AZEVEDO, Cecília e GONTIJO, Rebeca (Orgs.). Mitos, projetos e práticas políticas. Rio de Janeiro: Civilização Brasileira, 2009. p. 201-230.

Metamorfoses indígenas - Identidade e cultura nas aldeias coloniais do Rio de Janeiro. Rio de Janeiro: Arquivo Nacional, 2003.

ARRUTI, José Maurício. Mocambo: antropologia e história do processo de formação quilombola. Bauru/SP: Edusc, 2006.

BARTH, Fredrik. Grupos étnicos e suas fronteiras. In: POUTIGNAT, Philippe \& STREIFF-FENART, Jocelyne (Orgs.). Teorias da Etnicidade. São Paulo: Fundação Editora da Unesp, 1998.

BOSI, Alfredo. Um mito sacrificial: o indianismo de Alencar. In: . Dialética da colonização. 4. ed. São Paulo: Companhia das Letras, 2001.

CARVALHO, José Murilo de. Cidadania: tipos e percursos. Revista Estudos Históricos, n. 18, p. 1-21, 1996.

. Dimensiones de la ciudadanía em el Brasil del siglo XIX. In: SABATO, Hilda (Coord). Ciudadanía política y formación de las naciones. Perspectivas históricas de América Latina. México: FCE, COLMEX, FHA, 1999, p. 321-344.

CEZAR, Temístocles. A retórica da nacionalidade de Varnhagen e o mundo antigo: o caso da origem dos tupis. In: GUIMARĀES, Manoel Luiz Salgado (Org.). Estudos sobre a escrita da História. Rio de Janeiro: 7Letras, 2006, p. 29-41.

COSTA, Emília Viotti. Da Monarquia à República: momentos decisivos. São Paulo: Grijalbo, 1977.

COUTINHO, Afrânio. A Literatura no Brasil. Era Romântica. 6.ed. São Paulo: Global, 2002.

CUNHA, Manuela Carneiro da (Org.). Legislação indigenista no Século XIX. São Paulo: Edusp, 1992.

. Política indigenista no século XIX. In: CUNHA, Manuela Carneiro da (Org.). História dos Índios no Brasil. São Paulo: Companhia das Letras/Secretaria Municipal de Cultura/ Fapesp, 1992, p. 115-174.

DOMINGUES, Ângela. Quando os indios eram vassalos. Colonização e relações de poder no Norte do Brasil na segunda metade do século XVIII. Lisboa: Comissão Nacional para as Comemorações dos Descobrimentos Portugueses, 2000.

EISENBERG, José. As missōes jesuiticas e o pensamento político moderno. Belo Horizonte: Editora da UFMG, 2000.

FRANCO, Afonso Arinos de Melo. O Índio brasileiro e a Revolução Francesa - As origens brasileiras da teoria da bondade natural. 3.ed. Rio de Janeiro: Topbooks, sd.

GRINBERG, Keila. O fiador dos brasileiros - Cidadania, escravidão e Direito Civil no tempo de Antônio Pereira Rebouças. Rio de Janeiro: Civilização Brasileira, 2002.

JANCSÓ, István \& PIMENTA, João Paulo. Peças de um mosaico (ou apontamentos para o estudo da emergência da identidade nacional brasileira). In: MOTA, Carlos Guilherme (Org.). Viagem incompleta. A experiência brasileira (1500-2000). São Paulo: Editora Senac, 1999. p. 127-175.

HOBSBAWM, Eric. Naçôes e nacionalismos desde 1780. Rio de Janeiro: Paz e Terra, 1990.

LIMA, Henrique Espada. Sob o domínio da precariedade: escravidão e os significados da liberdade de trabalho no século XIX. Topoi, v. 6, n. 11, jul.-dez. 2005. p. 289-326.

MAMIGONIAN, Beatriz G. A harsh and gloomy fate. Liberated Africans in the service of the Brazilian State, 1830s-1860s. In: CURRY, Dawne, DUKE, Eric \& SMITH, Marshanda (Ed.). Extending the Diaspora. New Histories of Black People. Urabana/Chicago: University of Illinois Press, s/d.. p. 22-45. MARTINS, José de Souza. O cativeiro da terra. 6. ed. São Paulo: Hucitec, 1996.

MATTOS, Ilmar Rohloff de. O tempo saquarema. A formação do Estado Imperial. São Paulo: Hucitec, 1990. MAXWELL, Kenneth. Marquês de Pombal: paradoxo do iluminismo. 2.ed. Rio de janeiro: Paz e Terra, 1996. 
MENDES JÚNIOR, J. Os indígenas do Brasil, seus direitos, individuais e politicos. São Paulo: Typographia Hennies Irmãos, 1912.

MONTEIRO, John Manuel. Negros da terra: indios e bandeirantes nas origens de São Paulo. São Paulo: Companhia das Letras, 1994.

MOREIRA, Vânia Maria Losada. Terras indígenas do Espírito Santo sob o regime territorial de 1850. Revista Brasileira de História, v. 22, no 43, p. 153-169, 2002.

Caboclismo, vadiagem e recrutamento militar dos índios na província do Espírito Santo (1822-1875). Diálogos Latinoamericanos, n. 11, p. 94-120, 2005.

MOREIRA NETO, Carlos de Araújo. Os Índios e a Ordem Imperial. Brasília: CGDOC/Funai, 2005.

OLIVEIRA, João Pacheco de. Ensaios em Antropologia Histórica. Rio de Janeiro: Editora UFRJ, 1999.

OLIVEIRA, José Joaquim Machado de. Notas, apontamentos e notícias para a história da província do Espírito Santo. Revista do Instituto Histórico e Geográfico do Brazil, t. XIX, n. 22, p. 161-348, 1856.

RIBEIRO, Gladys Sabina. Nação e cidadania no jornal O Tamoio. Algumas considerações sobre José Bonifácio, sobre a Independência e a Constituinte de 1823. In: RIBEIRO, Gladys Sabina (Org.). Brasileiros e Cidadãos. São Paulo: Alameda, 2008.

RIO DE JANEIRO (província). Presidente (Soares de Souza). Relatório de 18 de outubro de 1836. Disponível em <http://brazilcrl.edu/bsd/bsd/u815/000008.html>.

SILVA, Joaquim Norberto de Souza e. Memória histórica e documentada das aldeias de índios da província do Rio de Janeiro. Revista do Instituto Histórico e Geográfico do Brazil, t. XVII, 3o Série, n. 14, p. 108-552, 1854.

SILVA, José Bonifácio de Andrada e. Apontamentos para a civilização dos índios bravos do Império do Brasil. In: CALDEIRA, Jorge (Org.). José Bonifácio de Andrada e Silva. São Paulo: Ed. 34, 2002, p. 183-199.

URICOECHEA, Fernando. O minotauro imperial. A burocratização do estado patrimonial brasileiro no século XIX. Rio de Janeiro-São Paulo: Difel, 1978.

VARNHAGEN, Francisco Adolpho de. Os indios bravos e o Sr. Lisboa, Timon $3^{\circ}$. Lima: Imprensa Liberal, 1867. . Memorial Orgânico. In: MOREIRA NETO, Carlos de Araújo. Os indios e a ordem imperial. Brasília: CGDOC/Funai, 2005, p. 334-347.

\section{RESUMO}

A transição do Brasil para a condição de nação independente gerou uma revisão na politica indigenista colonial com o objetivo de definir os parâmetros que o Império deveria adotar em relaçôes aos indios. Personagem destacado nesse processo foi José Bonifácio de Andrada e Silva, que apresentou à Assembleia Constituinte de 1823 uma detalhada proposta sobre o assunto. A dissolução da Assembleia Constituinte interrompeu o debate sobre os indios e a Constituição outorgada em 1824 abriu margem para considerá-los cidadãos. O objetivo deste artigo é analisar as estratégias indígenas e estatais no processo de definição dos direitos e das obrigaçôes inerentes à condiçãa de cidadãos, logo após a Independência, tomando como objeto de reflexão o periodo da Constituinte e a experiência dos indios da vila de Itaguaí, no Rio de Janeiro.

Palavras-chave: população indígena; cidadania; política indigenista; Primeiro Reinado; José Bonifácio de Andrada e Silva.

\section{ABSTRACT}

The transition of Brazil to the condition of independent nation induced a revision of the colonial Indian policy with the objective of defining the parameters that the Empire had to adopt regarding the Indian population. An important actor in this process was José Bonifácio de Andrada e Silva who presented a detailed proposal on this issue to the 1823 Constituent Assembly. The dissolution of the Constituent Assembly interrupted the debate, but the 1824 Constitution opened the possibility of considering Indians as citizens of the empire. This articles means to analyze the strategies of the Indians and of the State in the process of defining the rights and obligations inherent to the condition of citizen, immediately after the Independence, studying the Constituent period and the experience of the Indians of Itaguai Village in Rio de Janeiro. Keywords: Indian population; citizenship; Indian policy; First Reign; Jose Bonifácio de Andrada e Silva. 